\title{
HUBUNGAN PROSES DAN STRATEGI PEMBELAJARAN \\ KONSTRUKTIVISME TERHADAP PRESTASI BELAJAR \\ MATA PELAJARAN AKUNTANSI DENGAN MATERI POKOK \\ INVESTASI PESERTA DIDIK DI KELAS XI SMK \\ MUHAMMADIYAH 14 SIABU TAHUN PELAJARAN 2016-2017
}

\author{
${ }^{(1)}$ Fatimah Sahro dan ${ }^{(2)}$ Yani Sukriah Siregar, M.Si \\ (1) Mahasiswa FKIP Univeristas Muhammadiyah Tapanuli Selatan \\ ${ }^{(2)}$ Dosen FKIP Univeristas Muhammadiyah Tapanuli Selatan
}

\begin{abstract}
Abstrak
Metode Penelitian yang digunakan asosiatif adalah suatu hubungan antara dua variabel atau lebih yang kebetulan munculnya bersama. Jadi bukan bukan hubungan kuasal maupun interaktif. Kepustakaan (Library Research) dan Penelitian Lapangan (Field Research) dan jenis penelitiannya adalah asosiatif: "Suatu hubungan antara dua variabel atau lebih yang kebetulan munculnya bersama. Sedangkan populasi penelitian adalah 57 orang peserta didik, sebagai sampel adalah kelas XI dengan jumlah 57 peserta didik Jadi bukan hubungan maupun interaktif dengan mempergunakan perhitungan secara product moment oleh Person dengan rumus sebagai berikut :

$$
r_{x y}=\frac{\sum x y}{\sqrt{\left(\sum x^{2}\right) \cdot\left(\sum y^{2}\right)}}
$$

Berdasarkan analisa data diatas, maka diperoleh nilai $r_{x y}$ hitung $=1,000$. Selanjutnya penulis menetapkan nilai $r_{x y}$ tabel pada taraf kesalahan $5 \%$ dengan $N=57$ orang peserta didik adalah 0,266 dan taraf kesalahan $1 \%$ adalah 0,345 (lihat daftar harga $r$ terlampir). Untuk menguji kebenaran hipotesis dilakukan dengan ketentuan melihat hubungan nilai $r_{x y}$ hitung dengan $r_{x y}$ tabel, dimana apabila nilai $r_{x y}$ hitung lebih besar atau sama dengan $r_{x y}$ tabel maka hipotesis alternatif (Ha) tidak diterima kebenarannya dan $H_{0}$ diterima, dan sebaliknya apabila nilai $r_{x y}$ hitung lebih kecil

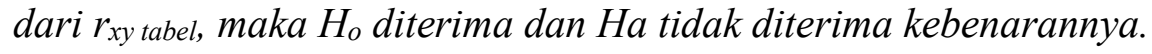

Kata Kunci: Strategi Pembelajaran, Prestasi Belajar, Akuntansi

\section{Pendahuluan}

Inti dari proses pendidikan secara keseluruhan adalah proses belajar mengajar.Proses belajar mengajar merupakan suatu proses yang mengandung serangkaian perbuatan guru dan peserta didik atas dasar hubungan timbal balik. Interaksi atau hubungan timbal balik dalam peristiwa belajar mengajar tidak sekedar 
hubungan antara guru dengan peserta didik saja, tetapi berupa interaksi .

Kontruktivisme merupakan aliran filsafat pengetahuan yang menekankan bahwa pengetahuan kita merupakan hasil konstruksi kita sendiri. Konstruktivisme sebagai aliran filsafat, banyak mempengaruhi konsep ilmu pengetahuan, teori belajar dan pembelajaran. Konstruktivisme menawarkan paradigma baru dalam dunia pembelajaran. Sebagai landasan paradigma pembelajaaran, konstruktivisme menyerukan perlunya partisipasi aktif peserta didik dalam proses pembelajaran, perlunya pengembagan peserta didik belajar mandiri, dan perlunya peserta didik memiliki kemampun untuk mengembangkan pengetahuannya sendiri.

Seruan tersebut memberi dampak terhadap landasan teori belajar dalam dunia pendidikan di Indonesia. Semula teori belajar dalam pendidikan Indonesia, lebih didominasi aliran psikologi behaviorisme. Akan tetapi saat ini, para pakar pendidikan di Indonesia banyak yang menyerukan agar landasan teori belajar mengaju pada aliran konstruktivisme. Akibatnya, orientasi pembelajaran di kelas mengalami pergeseran. Orientasi pembelajaran bergeser dari berpusat pada guru mengajar ke pembelajaran berpusat pada peserta didik.

Peserta didik tidak lagi diposisikan bagaikan bejana kosong yang siap diisi. Dengan sikap pasrah peserta didik disiapkan untuk dijejali informasi oleh gurunya. Atau peserta didik dikondisikan sedemikian rupa untuk menerima pengetahuan dari gurunya. Peserta didik kini diposisikan sebagai mitra belajar guru. Guru bukan satu-satunya pusat informasi dan yang paling tahu. Guru hanya salah satu sumber belajar atau sumber informasi. Sedangkan sumber belajar yang lain bisa teman sebaya, perpustakaan, alam, laboratorium, televisi, koran dan internet.

Padahal pelajaran akuntansi merupakan pengetahuan yang cukup menarik,apalagi di dukung dengan perkembangan ilmu pengetahuan dan teknologi yang semakin pesat. Seiring dengan berkembangnya ilmu pengetahuan dan teknologi yang sangat pesat maka perlu adanya pembaharuan (modernisasi) dalam pendidikan.Tanpa pendidikan yang memadai akan sulit bagi manusia untuk mencapai tujuan. Oleh karena itu pelajaran akuntansi termaksud salah satu mata pelajaran yang sangat penting.

Bagi aliran konstruktivisme, guru tidak lagi menduduki tempat sebagai pemberi ilmu. Tidak lagi sebagai satusatunya sumber belajar. Namun guru lebih diposisikan sebagai fasiltator yang memfasilitasi peserta didik untuk dapat belajar dan mengkonstruksi pengetahuannya sendiri. Aliran ini lebih menekankan bagaimana peserta didik belajar bukan bagaimana guru mengajar.

Sebagai fasilitator guru bertanggung jawab terhadap kegiatan pembelajaran di kelas. Diantara tanggung jawab guru dalam pembelajaran adalah menstimulasi dan memotivasi peserta didik. Mendiagnosis dan mengatasi kesulitan peserta didik serta menyediakan pengalaman untuk menumbuhkan pemahaman peserta didik. Oleh karena itu, guru harus menyediakan dan memberikan kesempatan sebanyak mungkin kepada peserta didik untuk belajar secara aktif. Sedemikian rupa sehingga para peserta didik dapat menciptakan, 
membangun, mendiskusikan, membandingkan, bekerja sama, dan melakukan eksperimentasi dalam kegiatan belajarnya.

Memperhatikan uraian diatas, nampanya pembelajaran dengan pendekatan problem posing sejalan dengan prinsip pembelajaran paradigma konstruktivisme. Melalui pembelajaran dengan pendekatan problem posing, peserta didik bisa belajar aktif dan mandiri. Ia akan membagun pengetahuannya dari yang sederhana menuju pengetahuan yang kompleks. Dan dengan bantuan guru, peserta didik bisa diarahkan untuk mengaitkan suatu informasi dengan informasi yang lainnya sehingga terbentuk suatu pemahaman baru.

Berdasarkan hasil obeservasi di SMK Muhammadiyah 14 Siabu, guru kurang menerapkan metode mengajar yang tepat agar peserta didik lebih tertarik dengan pelajaran akuntansi, sehingga sebagian besar peserta didik kurang aktif serta pengetahuan peserta didik masih terbatas dan kesadaran belajar peserta didik yang tipis,dan terdapatnya perpustakaan tetapi buku-buku yang disediakan tidak lengkap sehingga kegiatan kurang maksimal. Menyikapi masalah di atas perlu adanya upaya yang dilakukan oleh guru untuk menggunakan metode pembelajaran yang membuat peserta didik tertarik dan akhirnya membuat peserta didik tuntas dalam memahami materi yang disampaikan guru. Berdasarkan uraian diatas penulis untuk melaksanakan penelitian dengan judul: "Hubungan Proses Dan Strategi Pembelajaran Konstruktivisme Terhadap Prestasi Belajar Mata Pelajaran Akuntansi Dengan Materi Pokok Investasi Peserta
Didik Di Kelas XI SMK Muhammadiyah 14 Siabu Tahun Pelajaran 2016-2017.”

\section{Metode Penelitian}


Dalam penelitian ini pengumpulan data yang dilakukan untuk memperoleh data yang penulis butuhkan dilakukan dengan cara :

\section{Penelitian Kepustakaan (Library Research)}

Penelitian kepustakaan (Library Research) merupakan penelitian yang dilakukan dengan cara mengumpulkan data-data dari buku-buku literatur atau kepustakaan yang mempunyai hubungan erat dengan masalah yang diteliti di lapangan.

2. Penelitian Lapangan (Field Research) Penelitian lapangan (Field Research) merupakan penelitian yang dilakukan secara langsung ke lokasi yang akan diteliti. Pada kesempatan ini, penulis dapat langsung terjun kepada objek penelitian yaitu di kelas XI SMK Muhammadiyah 14 Siabu Tahun Pelajaran 2016-2017, dalam hal untuk mengetahui pengaruh metode pembelajaran kontruktivisme terhadap prestasi belajar peserta didik pada bidang studi akuntansi.

Jenis penelitian yang digunakan adalah asosiatif, Penelitian ini adalah penelitian yang bertujuan untuk mengetahui pengaruh dua variabel atau lebih, yaitu:
1. $\mathrm{X}=$ Hubungan proses dan stretegi pembelajaran kontruktivisme.

2. $\mathrm{Y}=$ Prestasi belajar peserta didik

\section{Pembahasan dan Hasil}

Berdasarkan penelitian yang dilakukan di SMK Muhammadiyah 14 Siabu dengan jumlah sampel penelitian sebanyak 57 orang peserta didik dengan melalui strategi pembelajaran konstruktivisme dan prestasi belajar mata pelajaran akuntansi dengan materi pokok inventasi pada kelas XI.

Tabel 1. Apakah menurut anda pembelajaran Konstruktivisme sudah pernah diterapkan guru dalam proses pembelajaran akuntansi?

\begin{tabular}{|c|l|c|c|}
\hline \multirow{2}{*}{ No. } & \multirow{2}{*}{$\begin{array}{c}\text { Alternatif } \\
\text { Jawaban }\end{array}$} & \multicolumn{2}{|c|}{$\begin{array}{c}\text { Jumlah peserta } \\
\text { didik 57 orang }\end{array}$} \\
\cline { 3 - 4 } & & $\frac{f}{n}$ & $\begin{array}{c}\text { Persentase } \\
(\%)\end{array}$ \\
\hline \multirow{3}{*}{1} & Ya & 0 & 0 \\
\cline { 2 - 4 } & $\begin{array}{l}\text { Kadang- } \\
\text { kadang }\end{array}$ & 0 & 0 \\
\cline { 2 - 4 } & Tidak & 57 & 100 \\
\hline \multicolumn{2}{|c|}{ Jumlah } & 57 & 100 \\
\hline
\end{tabular}

Berdasarkan soal yang di atas yaitu: "Apakah menurut anda pembelajaran Konstruktivisme sudah pernah diterapkan guru dalam proses pembelajaran akuntansi?" bahwa peserta didik yang memilih jawaban Ya sebanyak 0 orang dengan $0 \%$, Kadangkadang sebanyak 0 orang dengan $0 \%$ sedangkan Tidak sebanyak 57 orang peserta didik dengan $100 \%$. 
Tabel.2 Apakah guru akuntansi anda mempunyai persiapan melaksanakan pembelajaran Konstruktivisme?

\begin{tabular}{|c|l|c|c|}
\hline \multirow{2}{*}{ No } & \multirow{2}{*}{$\begin{array}{c}\text { Alternatif } \\
\text { Jawaban }\end{array}$} & \multicolumn{2}{|c|}{$\begin{array}{c}\text { Jumlah peserta didik } \\
\text { 57 orang }\end{array}$} \\
\cline { 3 - 4 } & $\frac{f}{n}$ & $\begin{array}{c}\text { Persentase } \\
(\%)\end{array}$ \\
\hline \multirow{3}{*}{2} & Ya & 52 & 91,22 \\
\cline { 2 - 4 } & $\begin{array}{l}\text { Kadang- } \\
\text { kadang }\end{array}$ & 0 & 0 \\
\cline { 2 - 4 } & Tidak & 5 & 8,78 \\
\hline \multicolumn{2}{|c|}{ Jumlah } & 57 & 100 \\
\hline
\end{tabular}

Berdasarkan soal yang di atas yaitu: "Apakah guru akuntansi anda mempunyai persiapan melaksanakan pembelajaran Konstruktivisme?" bahwa peserta didik yang memilih jawaban Ya sebanyak 52 orang dengan 91,22\%, Kadang-kadang sebanyak 0 orang dengan $0 \%$ sedangkan Tidak sebanyak 5 orang peserta didik dengan 8,78 $\%$.

Dalam perhitungan persentase, variabel X (hubungan proses dan stretegi pembelajaran kontruktivisme) diperoleh hasil dengan rata-rata 38,40 dan variabel $Y$ (prestasi belajar peserta didik pada bidang studi ekonomi dengan materi pokok invesntasi) diperoleh nilai rata-rata 37,84

Seterusnya dilakukan analisa data dengan menggunakan rumus korelasi product moment, yaitu $r_{x y}$ hitung $=1,000$ Nilai ini kemudian dibandingan dengan nilai $\mathrm{r}_{\mathrm{xi}}$ tabel pada taraf kesalahan $5 \%$ dengan $\mathrm{N}=57$ adalah 0,666, dan taraf kesalahan $1 \%$ adalah 0,345, dimana $r$ hitung lebih besar dari $r$ tabel.

Hal ini menunjukkan bahwa ada hubungan proses strategi pembelajaran konstruktivisme terhadap prestasi belajar mata pelajaran akuntansi dengan materi pokok investasi peserta didik di kelas XI SMK Muhammadiyah 14 Siabu Tahun Pelajaran 2016-2017. Dalam pelaksanaan pembelajaran konstruktivisme adalah merupakan yang efesien menurut yang diteliti di SMK Muhammadiyah 14 Siabu, hendaknya bagi para guru Ekonomi dapat lebih melanjutkan dengan model pembelajaran konstruktivisme agar peserta didik dapat meningkatkan prestasi belajar serta minat belajar peserta didik semakin naik.

\section{Kesimpulan}

Berdasarkan hasil analisis hubungan proses strategi pembelajaran konstruktivisme terhadap prestasi belajar mata pelajaran akuntansi, berdasar analisa data yang diperoleh bahwa adalah:

1. Sesuai dengan analisa hasil yang diperoleh perhitungan $r_{x y}=1,000$ berdasarkan perhitungan product moment menunjukkan harga kritik $r$ dengan tingkat kepercayaan $5 \%$ dengan $\mathrm{N}=57$ adalah 0,266, dan taraf kesalahan $1 \%$ adalah 0,345, sehingga hasil yang diperoleh adalah 1,000.

2. Berdasarkan hasil yang diperoleh bahwa strategi pembelajaran konstruktivisme menunjukkan ada hubungan ini terlihat $1,000<0,266-0,345$ harga kritik $r$ yang terdapat pada harga $\mathrm{r}$

3. Sesuai dengan prestasi yang diperolah maka penulis menyimpulkan bahwa ada hubungan proses strategi pembelajaran konstruktivisme terhadap prestasi belajar mata pelajaran akuntansi dengan materi pokok investasi peserta didik di kelas XI 
SMK Muhammadiyah 14 Siabu Tahun Pelajaran 2016-2017

\section{Saran}

Sehubungan dengan penelitian yang telah penulis lakukan, peneliti memberikan saran sebagai berikut:

1. Kepada Bapak/ibu guru bidang studi ekonomi agar dapat menyesuaikan stretegi pembelajaran yang baik sesuai dengan materi yang akan disampaikan agar peserta didik lebih mudah memahami materi yang akan disampaikan dalam proses belajar mengajar.

2. Dari hasil penelitian menunjukkan tidak adanya hubungan strategi pembelajaran konstruktivisme bidang studi Ekonomi

3. Perlunya dilakukan penelitian pada permasalahan yang relevan untuk dijadikan perbandingan dan masukan yang konstruktif terhadap hasil penelitian ini.

\section{Daftar Pustaka}

Azwar Syaifuddin, 2010, Metode Penelitian. Yogyakarta: Pustaka Pelajar Arikunto Suharsimi, 2006. Prosedur Penelitian Suatu Pendekatan Praktik, Jakarta: Rineka Cipta

Achmad Sugandi dkk, 2004, Teori pembelajaran .Semarang: Unnes Press

Budiningsi C.Asri, 2010, Belajar dan Pembelajaran, Jakarta: Rineka Cipta

Bahri Syaiful dan Aswan Zain, 2007, Strategi Belajar Mengajar .Jakarta: Rineka Cipta
Deliarnov 2003, Perkembangan Pemikiran Ekonomi. Jakarta: PT, Raja Grafindo Persada

Dalyono.M, 2010, Psikologi Pendidikan, Jakarta: PT Rineka Cipta

Erman Suherman dkk.2003 Strategi Pembelajaran Kontemporer. Bandung: JICA-Universitas Pendidikan Indonesia Hadi Sutrisno, 2002 Metodologi Penelitian Pendidikan. Bandung: Pustaka Setia

Masrum, 2003, Metodologi Research, Yogyakarta: UGM

Masri Singarimbun, dan Efendi,Sofyan, 2006, Metode Penelitian Survei LP3ES. Jakarta

Netra I.B, 2004, Statistik Infrensial, Surabaya: Usaha Nasional 